\title{
Identification of potential Campylobacter jejuni genes involved in biofilm formation by EZ-Tn 5 Transposome mutagenesis
}

\author{
Amy Huei Teen Teh ${ }^{1}$, Sui Mae Lee ${ }^{1}$ and Gary A. Dykes ${ }^{2^{*}}$ (i)
}

\begin{abstract}
Background: Biofilm formation has been suggested to play a role in the survival of Campylobacter jejuni in the environment and contribute to the high incidence of human campylobacteriosis. Molecular studies of biofilm formation by Campylobacter are sparse.

Results: We attempted to identify genes that may be involved in biofilm formation in seven C. jejuni strains through construction of mutants using the EZ-Tn5 Transposome system. Only 14 mutants with reduced biofilm formation were obtained, all from one strain of C. jejuni. Three different genes of interest, namely $\mathrm{CmeB}$ (synthesis of multidrug efflux system transporter proteins), NusG (transcription termination and anti-termination protein) and a putative transmembrane protein (involved in membrane protein function) were identified. The efficiency of the EZ::TN5 transposon mutagenesis approach was strain dependent and was unable to generate any mutants from most of the strains used.
\end{abstract}

Conclusions: A diverse range of genes may be involved in biofilm formation by C. jejuni. The application of the EZ::TN5 system for construction of mutants in different Campylobacter strains is limited.

Keywords: Biofilm, Campylobacter jejuni, Transposon mutagenesis, EZ-Tn5 Transposome

\section{Background}

Campylobacter jejuni is a Gram negative, microaerophilic bacterial species with fastidious temperature, atmosphere and nutrient growth requirements [1]. Despite these requirements, C. jejuni is one of the most frequent causes of human bacterial gastrointestinal food-borne infection worldwide [2]. Common symptoms associated with infection by this pathogen include diarrhea, fever and abdominal pain which may also lead to more serious neuropathies such as Guillain-Barre and Miller-Fisher syndromes $[3,4]$.

Campylobacter jejuni is widely spread in the environment and can be readily isolated from food, water and other sources $[5,6]$. Biofilm formation has been suggested to help C. jejuni overcome the disadvantages of

${ }^{*}$ Correspondence: gary.dykes@curtin.edu.au

2 School of Public Health, Curtin University, Bentley, WA 6102, Australia

Full list of author information is available at the end of the article survival in the environment by protecting the bacteria from various stressors $[7,8]$.

While biofilm formation by other bacterial species, such as Pseudomonas aeruginosa and Escherichia coli are well studied, molecular studies of biofilm formation by Campylobacter are sparse. A study carried out by Reeser et al. [9] showed that flagella plays a role in biofilm formation by Campylobacter. These authors reported that flagellum-deficient mutant strains (fla $A B$ mutant strains) showed lower levels of biofilm formation. In addition, biofilm formation by Campylobacter was impaired in strains defective in a putative flagellar protein (FliS) and in phosphate acetyltransferase (Cj0688) [10]. A study carried out by Fields, Thompson [11] showed that biofilm formation was lowered in C. jejuni strains with a mutated CsrA (carbon starvation regulator) gene. The product of this gene in other bacterial species has been identified as a posttranscriptional regulator of translation responsible for repression or activation of many important processes, 
including regulation of the stress response [11, 12]. A study by Oh and Jeon [13] showed that biofilm formation by $C$. jejuni was increased in strains with a mutated alkyl hydroperoxide reductase (AhpC) gene, which is involved in the oxidative stress response.

Although there is evidence for the role of flagella and gene regulation in biofilm formation, molecular understanding of biofilm formation by $C$. jejuni is still in its infancy. In this study, we attempted to identify novel genes that may be involved in biofilm formation by $C$. jejuni through random mutagenesis as this is established as a useful tool in deducing gene function [14]. Since transposons have been widely used in the construction of mutant libraries due to their ability to randomly insert into the genome, an in vivo transposition system, the EZ-Tn5 Transposome (Epicentre, USA), was used in this study. The EZ::TN5 transposome can be generated in vitro using purified EZ::TN5 transposase and a DNA fragment (usually antibiotic cassette) flanked by inverted repeats. This system has been shown to be an efficient and reliable method of random insertion of transposon DNA into the genome of many different microorganisms in numerous studies [14-16].

\section{Methods}

\section{Bacterial strains and growth conditions}

Seven C. jejuni strains (2862, 2863, 2865, 2866, 2868, 2869 and 2871) isolated from poultry obtained from retail outlets in Malaysia as reported by Wieczorek et al. [17] were used in this study. Campylobacter jejuni ATCC 33291 obtained from the American Type Culture Collection was also used in this study. Whole genomes of three of the strains, 2865, 2868 and 2871, were sequenced as described in Teh et al. [18]. All the strains were maintained at $-80{ }^{\circ} \mathrm{C}$ in Nutrient Broth No. 2 (NB2, Oxoid, UK) and 15\% glycerol and were resuscitated on Campylobacter blood-free selective agar base (Oxoid, UK) (as sessile cultures) with incubation at $37{ }^{\circ} \mathrm{C}$ for $48 \mathrm{~h}$ under microaerobic conditions generated using Campygen (Oxoid, UK).

\section{Construction of transposon mutants of $C$. jejuni EZ-Tn5 transposome preparation}

An attempt was made to construct a transposon library for each of eight $C$. jejuni strains using the EZ-Tn5 transposase and the EZ-Tn5 pMOD-3<R6Kyori/MCS > transposon construction vector (Epicenter Biotechnologies, USA) in vivo according to the manufacturer's instructions. A chloramphenicol $(\mathrm{Cm})$ resistance cassette was amplified from pBACe3.6 (GenBank Accession No. U80929) [19] using primers CmF (5'-GAATTCGATCGGCACGTAAGAGGTTC- $3^{\prime}$ ) and CmR (5'-AAGCTTGGGCACCAATAA CTGCCTTA-3') which resulted in a PCR product of $788 \mathrm{bp}$. The purified $\mathrm{Cm}$ resistance gene cassette was then ligated into pGEM-T vector (Promega, USA) and transformed into Top-10 E. coli competent cells and plated on Luria-Bertani (LB) plate supplemented with $30 \mu \mathrm{g} / \mathrm{mL}$ $\mathrm{Cm}$. The pGEM-T::Cm was extracted from positive clones using the PureLink Quick Plasmid Miniprep Kit (Invitrogen, USA) and subjected to restriction digestion with EcoRI and HindIII before cloning into EcoRI and HindIIIdigested EZ-Tn5 pMOD-3<R6 Kyori/MCS $>$ to yield the EZ-Tn5-Cm transposon vector. The vector was then transformed into E. coli Top-10 competent cells and plated on LB plate supplemented with $30 \mu \mathrm{g} / \mathrm{mL} \mathrm{Cm}$. Positive clones were selected and plasmids were extracted. The EZ-Tn5$\mathrm{Cm}$ transposon region was amplified by PCR using primers PCRFP (5'-ATTCAGGCTGCGCAACTGT-3') and PCRRP (5'-GTCAGTGAGCGAGGAAGCGGAAG-3') and purified. EZ-Tn5 Transposomes was prepared by adding $2 \mu \mathrm{L}$ of EZ-Tn 5 transposon DNA, $4 \mu \mathrm{L}$ of EZ-Tn 5 transposase and $2 \mu \mathrm{L}$ of glycerol. The reaction mixture was incubated for $30 \mathrm{~min}$ at room temperature. The resulting mixture was stored at $-20{ }^{\circ} \mathrm{C}$ and used for mutagenesis of C. jejuni.

\section{Preparation of electrocompetent cells}

Electrocompetent $C$. jejuni strains were prepared as described previously [20]. Briefly, bacteria from a lawn grown overnight on Skirrow agar were harvested into $2 \mathrm{~mL}$ Mueller-Hinton (MH) broth, pelleted at $3220 \times g$ for $20 \mathrm{~min}$ at $4{ }^{\circ} \mathrm{C}$, and resuspended in $2 \mathrm{~mL}$ ice-cold wash buffer (272 mM sucrose, 15\% glycerol). The washing step was repeated for three times and the bacteria were then resuspended in $1 \mathrm{~mL}$ ice-cold wash buffer. Cells were aliquoted in $100 \mu \mathrm{L}$ and stored at $-80{ }^{\circ} \mathrm{C}$ until needed.

\section{Electroporation conditions}

Electroporation was performed as described previously [20]. One milliliter of the transposome was added into $100 \mu \mathrm{L}$ C. jejuni electrocompetent cells in a $0.2 \mathrm{~cm}$ electroporation cuvette on ice and gently mixed. Electroporation was performed with a Bio-Rad MicroPulser $(2.5 \mathrm{kV}$, $600 \Omega$, and $10 \mu \mathrm{F})$ (Bio-Rad, USA). Following electroporation, $200 \mu \mathrm{L}$ of SOC broth (2\% Bacto Tryptone (Difco, US), $0.5 \%$ yeast extract (Difco, US), $10 \mathrm{mM} \mathrm{NaCl}, 2.5 \mathrm{mM}$ $\mathrm{KCl}, 10 \mathrm{mM} \mathrm{MgCl} 2,10 \mathrm{mM} \mathrm{MgSO}_{4}, 20 \mathrm{mM}$ glucose) was added to the electroporated cells and the mixture spread onto Campylobacter blood-free selective agar plates. Plates were incubated for $24 \mathrm{~h}$ microaerobically, and bacteria were then harvested into $1 \mathrm{~mL} \mathrm{NB2}$ broth, centrifuged at $10,000 \times g$ for $2 \mathrm{~min}$, resuspended in $100 \mu \mathrm{L}$ NB2 broth, and plated onto Campylobacter blood-free selective agar containing $30 \mu \mathrm{g} / \mathrm{mL} \mathrm{Cm}$ to select for transformants. Colonies were individually patched to fresh Campylobacter blood-free selective agar-Cm plates to 
confirm resistance, followed by inoculation into NB2 broth, growth for 2 days under microaerobic conditions, and storage at $-80^{\circ} \mathrm{C}$ in $15 \%$ glycerol.

\section{Assessment of biofilm formation}

The ability of the original $C$. jejuni strains and transposon mutants to form biofilm was determined in 96-well polystyrene microtiter plates $\left(\mathrm{TPP}^{\circledR}\right.$, Switzerland) using Mueller-Hinton broth (MHB) and Brucella broth under microaerobic and aerobic conditions by the methods described by Skyberg et al. [21] with slight modifications. Briefly, the strains were grown as sessile cultures under microaerobic conditions for $48 \mathrm{~h}$ at $37{ }^{\circ} \mathrm{C}$. After incubation, the colonies on the agar plates were harvested by suspending in $5 \mathrm{~mL}$ of phosphate buffer saline (PBS; 1st BASE, Singapore). The cells were then diluted 1:10 in MHB or Brucella broth $\left(\sim 10^{7} \mathrm{CFU} / \mathrm{mL}\right)$ and a $200 \mu \mathrm{L}$ aliquot of each dilution was transferred to a microtiter plate well. Six wells per microtiter plate were used for each strain and a further six wells were filled with uninoculated medium which serve as negative control. The plates were then incubated at $37{ }^{\circ} \mathrm{C}$ for 6 days under microaerobic or aerobic conditions without shaking. The assays were performed in triplicate. The wells were then examined using the crystal violet and the absorbance was determined using a microplate reader (Tecan, Switzerland) at $550 \mathrm{~nm}$.

\section{Determination of EZ-Tn5-Cm insertion sites}

Genomic DNA was extracted from the mutants impaired in biofilm formation using Wizard Genomic DNA Purification Kit (Promega, USA). This DNA was used as the template for a single-primer PCR amplification known as RATE (Random Amplification of Transposon Ends) as described previously [15]. PCR amplification was carried out using SqFP (5'-GCCAACGACTACGCACTAGCC AAC- $3^{\prime}$ ), which binds within the transposon. The PCR conditions used were as follow: 30 cycles at $95^{\circ} \mathrm{C}$ for $30 \mathrm{~s}$, $55{ }^{\circ} \mathrm{C}$ for $30 \mathrm{~s}$, and $72{ }^{\circ} \mathrm{C}$ for $3 \mathrm{~min} ; 30$ cycles at $95^{\circ} \mathrm{C}$ for $30 \mathrm{~s}, 30{ }^{\circ} \mathrm{C}$ for $30 \mathrm{~s}$, and $72{ }^{\circ} \mathrm{C}$ for $2 \mathrm{~min}$; and 30 cycles at $95{ }^{\circ} \mathrm{C}$ for $30 \mathrm{~s}, 55^{\circ} \mathrm{C}$ for $30 \mathrm{~s}$, and $72{ }^{\circ} \mathrm{C}$ for $2 \mathrm{~min}$. The amplified PCR product was then sent for sequencing and the transposon insertion site was identified by Basic Local Alignment Search Tool (BLAST) analysis of the DNA sequence immediately flanking the mosaic end of the transposon [22].

\section{Statistical analysis}

Biofilm formation assays were performed in triplicate using independently grown cultures. All the statistical analysis was performed using SPSS 18 software. Data obtained was analyzed using one way analysis of variance (ANOVA) and pairwise comparisons of the means were conducted using Tukey's post hoc test at a 95\% confidence level.

\section{Results and discussion}

Transposon mutagenesis of $C$. jejuni

In order to identify the genes that are involved in biofilm formation, an attempt was made to construct a transposon library for each of eight $C$. jejuni strains by transposon mutagenesis and the ability of individual mutants to form biofilm was then screened and compared to that of the original strain. A stable transposome complex consisting of EZ-Tn5 transposons containing a chloramphenicol resistance cassette (EZ-Tn $<<\mathrm{Cm}>$ transposon) was constructed in vitro in the absence of $\mathrm{Mg}^{2+}$. The transposomes formed were then electroporated into $C$. jejuni competent cells where the transposase was activated by intracellular $\mathrm{Mg}^{2+}$ leading to random insertion of the transposon into $C$. jejuni genomic DNA. This in vivo protocol successfully generated $\mathrm{Cm}^{\mathrm{R}}$ mutants in C. jejuni 2868. The number of mutants generated was, however, very low with only 37 mutants recovered. Out of these 37 mutants, only 22 remained viable when resuscitated from frozen stock. No mutant was generated from the other seven strains used in this study. These results suggest that the efficiency of transposon mutagenesis is strain-dependent. A similar finding was reported in a previous study where the EZ-Tn5 transposon system successfully generated a large number of mutants in $C$. jejuni 81-176 but a low number or no mutants were obtained from other $C$. jejuni strains including the $C$. jejuni ATCC 33291 strain used in our study [16]. This result may be due to the presence of specific restriction-modification systems in selected $C$. jejuni strains, especially the wild type strains used in this study. Previous studies have shown that the EZ-Tn5 transposon system successfully generated transposition mutants effectively in different bacterial species including Escherichia coli [23], Salmonella enterica serovar Typhi [24], Neisseria gonorrhoeae [15] and Bacteroides fragilis [25]. The results obtained from this study, however, indicate that the potential for application of in vivo transposon mutagenesis in Campylobacter strains might be limited due to this straindependent transposition efficiency [16].

\section{Screening of biofilm forming ability of the mutant strains}

All the 22 mutant strains generated from strain 2868 were screened for biofilm formation and the results are shown in Fig. 1. In general, levels of biofilm formed in $\mathrm{MH}$ broth were significantly higher $(\mathrm{p}<0.05)$ as compared to Brucella broth as shown in the results of one way ANOVA with Tukey's post hoc test presented in Additional file 1: Table S1. In addition, most of the mutant strains showed no significant difference $(p>0.05)$ in biofilm formation 

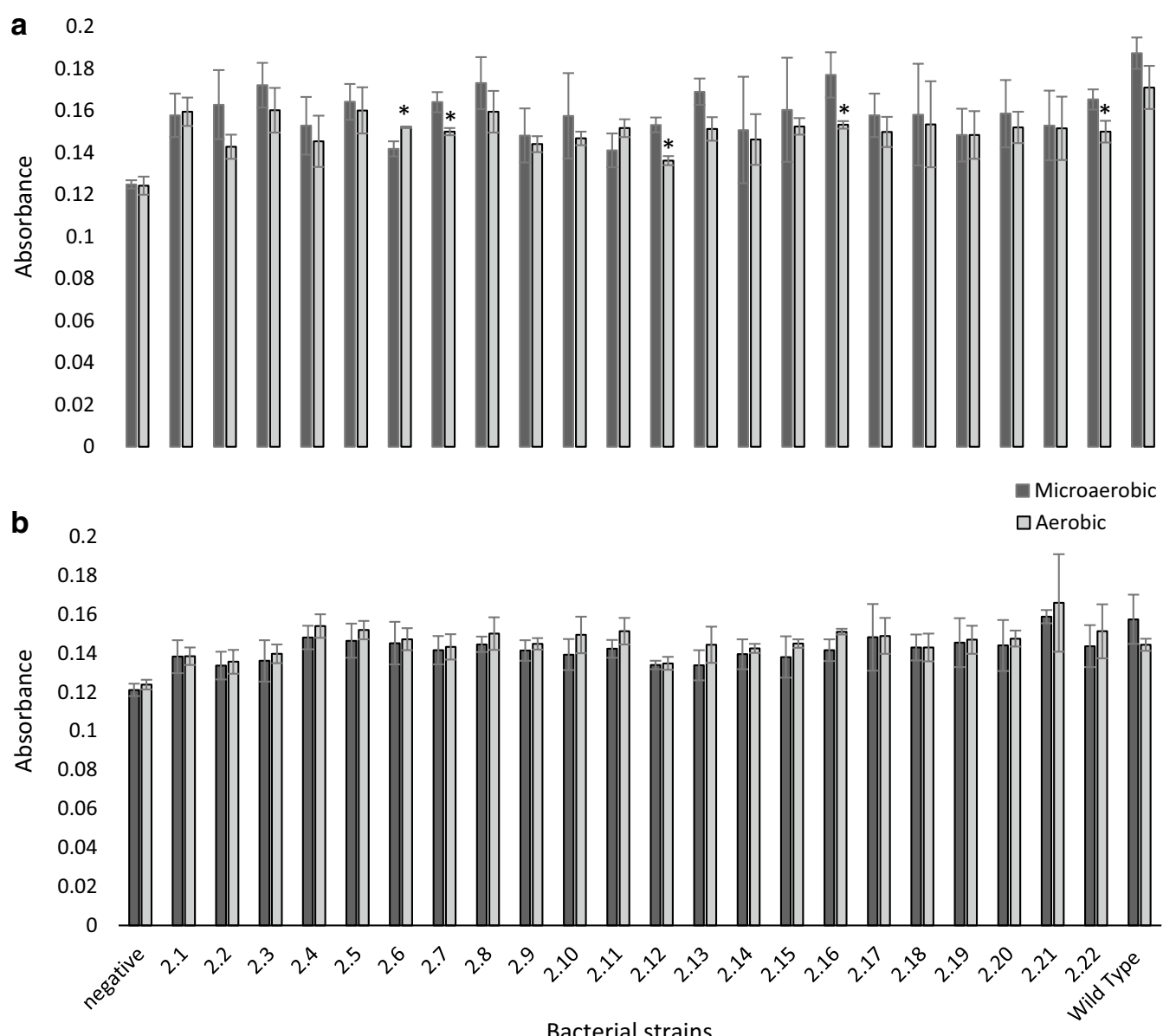

Fig. 1 Comparison of biofilm formation by Campylobacter jejuni 2868 mutant strains, strains 2.1-2.22 obtained through transposon mutagenesis using the EZ-Tn5 Transposome mutagenesis system, grown in a Mueller-Hinton Broth; b Brucella Broth and incubated for 6 days at $37^{\circ} \mathrm{C}$. The negative is uninoculated medium. All results are presented in mean $\pm S D$ where $n=3$; Symbol asterisk indicates significant difference on biofilm formed under microaerobic and aerobic conditions within the same bacterial strain where $p<0.05$

when incubated in $\mathrm{MH}$ under different oxygen conditions. Nevertheless, 4 out of 22 strains showed a significant decrease $(\mathrm{p}<0.05)$ while one strain showed a significant increase $(\mathrm{p}<0.05)$ in biofilm formation under aerobic condition as compared to microaerobic condition. This suggested that the gene that was disrupted in these mutant strains may be involved in the oxidative stress response. On the other hand, all the strains showed no significant difference $(\mathrm{p}>0.05)$ in biofilm formation when incubated under aerobic or microaerobic conditions in Brucella broth. This may be due to the presence of sodium bisulfite in Brucella broth which acts as a reducing agent and protects the bacteria from oxygen stress when incubated under aerobic condition. This is consistent with previous study which showed that the presence of supplement containing reducing agents, for example sodium metabisulphite and sodium pyruvate, minimized the conversion of rods to coccoid forms of $C$. jejuni, which occur when conditions are unfavourable for its growth [26].

\section{Determination of genes disrupted in the mutants with decreased biofilm formation}

Since most of the strains showed higher biofilm formation in $\mathrm{MH}$ under microaerobic conditions, a one way ANOVA was carried out to establish if the biofilm forming ability of the mutant strains was different as compared to the wild type strain under these conditions. The results showed that 14 out of the 22 mutant strains (strains 2.1, 2.4-2.7, 2.9, 2.11-2.13, 2.17, 2.19-2.22) showed significantly lower $(\mathrm{p}<0.05)$ biofilm formation as compared to the wild type strain. The reduction in biofilm formation was, however, low as compared to other studies that investigated the role of 
specific genes on biofilm formation by $C$. jejuni through construction of different mutant strains $[10,11]$. This might be due to the originally low biofilm formation in the wild type strain (strain 2868) used in our study, which may be a common occurrence among $C$. jejuni in general [27].

The insertion site of EZ-Tn $5<\mathrm{Cm}>$ transposon in the 14 mutants above were identified through RATE (Random Amplification of Transposon Ends) PCR and the sequences obtained were subjected to BLAST and were compared to the available C. jejuni NCTC 11168 genomic sequence [28] to identify the mutated gene. The location of transposons in 4 out of the 14 mutants occurred in coding regions and the genes disrupted are listed in Table 1. It is likely that the transposons inserted in noncoding regions in the other mutants as no genes could be identified.

Genes disrupted in mutants displaying decreased biofilm formation were identified as $\mathrm{CmeB}$ (multidrug efflux system transporter protein synthesis), NusG (transcription termination and anti-termination) and a putative transmembrane protein (involved in membrane protein function). Several studies have shown that defective in efflux pump activity impairs biofilm formation in different bacterial species (Escherichia coli, Klebsiella, Salmonella, Pseudomonas aeruginosa and Staphylococcus aureus) [29-32]. This may also contribute to lower biofilm formation in mutant strain 2.9 in this study. The presence of hydrophobic components on the surface of bacterial cells will contribute to cell surface hydrophobicity and promote bacteria adhesion and contribute to biofilm formation [33, 34]. Similarly, capsular polysaccharides (CPS) and lipooligosachharides

Table 1 Identification of EZ-Tn5 $<\mathrm{Cm}>$ transposon insertion sites in C. jejuni 2868 mutants with decreased biofilm formation

\begin{tabular}{|c|c|c|c|}
\hline $\begin{array}{l}\text { Mutant } \\
\text { strain }\end{array}$ & $\begin{array}{l}\text { Locus desig- } \\
\text { nation }\end{array}$ & Gene & $\begin{array}{l}\text { Putative gene } \\
\text { function }\end{array}$ \\
\hline 2.9 & N/A & CmeB & $\begin{array}{l}\text { Transporter } \\
\text { protein, part of a } \\
\text { multidrug efflux } \\
\text { system }\end{array}$ \\
\hline 2.11 & Cj0473 & NusG & $\begin{array}{l}\text { NusG is a bacterial } \\
\text { transcriptional } \\
\text { elongation } \\
\text { factor involved } \\
\text { in transcription } \\
\text { termination and } \\
\text { anti-termination }\end{array}$ \\
\hline 2.19 & Cj0268c & $\begin{array}{l}\text { Membrane protein/ } \\
\text { transmembrane } \\
\text { protein }\end{array}$ & $\begin{array}{l}\text { Probable trans- } \\
\text { membrane } \\
\text { protein }\end{array}$ \\
\hline
\end{tabular}

N/A not available
(LOS) will affect cell surface hydrophobicity, autoaggregation and attachment of many Campylobacter strains to cell lines and abiotic surfaces [35-37]. This may indicate that the gene involved in membrane protein synthesis may affect the cell integrity of the outer membrane of mutant strain 2.19 which in turn may affect its biofilm formation.

Overall, our study indicated that the utilization of an in vivo transposon mutagenesis approach using the EZ::TN5 system could, in principle, identify genes involved in biofilm formation by $C$. jejuni. The role of these genes in biofilm formation is, at this stage, only putative, and further studies, including gene complementation, need to be carried out to confirm their role. The strains and growth conditions used in this study for biofilm formation were established as suitable in previous studies [38,39], however, a combination of different strains and growth conditions may result in higher biofilm formation and potentially different outcomes.

Notably, our study also showed that the EZ::TN5 system was unable to generate mutants from most of the strains used. Furthermore, the relative inefficiency in generating mutants in strains in which this can occur means that repeating the process until sufficient mutants are gathered may be required. This suggested that the efficiency of this transposon mutagenesis approach was strain dependent and its application is likely limited for use in C. jejuni.

\section{Additional file}

Additional file 1: Tables S1. One way ANOVA and Tukey's Post Hoc comparison showing the biofilm formation by the Campylobacter jejuni strains in different type of media (Muller-Hinton or Brucella broth) incubated under different oxygen conditions (aerobic or microaerobic).

\section{Abbreviations}

ANOVA: analysis of variance; ATCC: American type culture collection; BLAST: Basic local alignment search tool; CFU: colony forming unit; Cm: chloramphenicol; MH: Mueller-Hinton; NB2: Nutrient Broth No. 2; PBS: phosphate buffer saline; PCR: polymerase chain reaction; RATE PCR: random amplification of transposon ends polymerase chain reaction; SD: standard deviation.

Authors' contributions

AHTT carried out the transposon mutagenesis experiment, biofilm formation assay, statistical analysis and drafted the manuscript. SML reviewed and revised the manuscript. GAD contributed to the design of the study and reviewed and revised the manuscript. All authors read and approved the final manuscript.

Author details

${ }^{1}$ School of Science, Monash University, Jalan Lagoon Selatan, Bandar Sunway 46150, Selangor Darul Ehsan, Malaysia. ${ }^{2}$ School of Public Health, Curtin University, Bentley, WA 6102, Australia.

\section{Acknowledgements}

The authors acknowledge Monash University, Malaysia for providing financial support for this study. 


\section{Competing interests}

The authors declare that they have no competing interests.

\section{Availability of data and materials}

The dataset supporting the conclusions of this article is included within the article and its additional file.

\section{Publisher's Note}

Springer Nature remains neutral with regard to jurisdictional claims in published maps and institutional affiliations.

Received: 18 May 2016 Accepted: 5 May 2017

Published online: 12 May 2017

\section{References}

1. Keener K, Bashor M, Curtis P, Sheldon B, Kathariou S. Comprehensive review of Campylobacter and poultry processing. Compr Rev Food Sci Food Saf. 2004:3(2):105-16.

2. Jacobs-Reitsma W, Lyhs U, Wagenaar J, Nachamkin I, Szymanski C, Blaser M. Campylobacter in the food supply. Campylobacter. 3rd ed. Washington: American Society of Microbiology; 2008. p. 627-44.

3. Young VB, Mansfield L. Campylobacter infection-clinical context. Campylobacter: Molecular and cellular biology. Wymondham: Horizon Bioscience; 2005. p. 1-12

4. Salloway S, Mermel LA, Seamans M, Aspinall GO, Nam Shin JE, Kurjanczyk LA, et al. Miller-Fisher syndrome associated with Campylobacter jejuni bearing lipopolysaccharide molecules that mimic human ganglioside GD3. Infect Immun. 1996;64(8):2945-9.

5. Baylis CL, MacPhee S, Martin KW, Humphrey TJ, Betts RP. Comparison of three enrichment media for the isolation of Campylobacter spp. from foods. J Appl Microbiol. 2000:89(5):884-91. doi:10.1046/j.1365-2672.2000.01203.x.

6. Martínez-Rodriguez A, Kelly AF, Park SF, Mackey BM. Emergence of variants with altered survival properties in stationary phase cultures of Campylobacter jejuni. Int J Food Microbiol. 2004;90(3):321-9.

7. Buswell CM, Herlihy YM, Lawrence LM, McGuiggan JTM, Marsh PD, Keevil $\mathrm{CW}$, et al. Extended survival and persistence of Campylobacter spp. in water and aquatic biofilms and their detection by immunofluorescentantibody and -rRNA staining. Appl Environ Microbiol. 1998;64(2):733-41

8. Kalmokoff M, Lanthier P, Tremblay T-L, Foss M, Lau PC, Sanders G, et al. Proteomic analysis of Campylobacter jejuni 11168 biofilms reveals a role for the motility complex in biofilm formation. J Bacteriol. 2006;188(12):4312-20. doi:10.1128/jb.01975-05.

9. Reeser RJ, Medler RT, Billington SJ, Jost BH, Joens LA. Characterization of Campylobacter jejuni biofilms under defined growth conditions. Appl Environ Microbiol. 2007;73(6):1908-13. doi:10.1128/aem.00740-06.

10. Joshua GWP, Guthrie-Irons C, Karlyshev AV, Wren BW. Biofilm formation in Campylobacter jejuni. Microbiology. 2006;152(2):387-96. doi:10.1099/ mic 0.28358-0.

11. Fields JA, Thompson SA. Campylobacter jejuni CsrA mediates oxidative stress responses, biofilm formation, and host cell invasion. J Bacteriol. 2008;190(9):3411-6. doi:10.1128/jb.01928-07.

12. Romeo T, Gong M. Genetic and physical mapping of the regulatory gene csrA on the Escherichia coli K-12 chromosome. J Bacteriol. 1993:175(17):5740.

13. Oh $\mathrm{E}$, Jeon B. Role of alkyl hydroperoxide reductase (AhpC) in the biofilm formation of Campylobacter jejuni. PLoS ONE. 2014;9(1):e87312.

14. Veeranagouda Y, Husain F, Wexler HM. Transposon mutagenesis of the anaerobic commensal, Bacteroides fragilis, using the EZ:TN5 transposome. FEMS Microbiol Lett. 2012;333(2):94-100. doi:10.1111/j.1574-6968.2012.02602.x.

15. Ducey TF, Dyer DW. Rapid identification of EZ:: $\mathrm{TN}^{\mathrm{TM}}$ transposon insertion sites in the genome of Neisseria gonorrhoeae. Epicentre Forum. 2002;9:6-7.

16. Lin J, Wang Y, Van Hoang K. Systematic identification of genetic loci required for polymyxin resistance in Campylobacter jejuni using an efficient in vivo transposon mutagenesis system. Foodborne Pathog Dis. 2009;6(2):173-85.

17. Wieczorek K, Dykes GA, Osek J, Duffy LL. Antimicrobial resistance and genetic characterization of Campylobacter spp. from three countries. Food Control. 2013:34(1):84-91.

18. Teh AHT, Lee SM, Dykes GA. Draft genome sequences of three multiantibiotic-resistant Campylobacter jejuni strains $(2865,2868$, and 2871) isolated from poultry at retail outlets in Malaysia. Genome Announc. 2016:4(3):e00331. doi:10.1128/genomeA.00331-16.

19. Frengen E, Weichenhan D, Zhao B, Osoegawa K, van Geel M, de Jong PJ. A modular, positive selection bacterial artificial chromosome vector with multiple cloning sites. Genomics. 1999;58(3):250-3. doi:10.1006/ geno.1998.5693.

20. Van Vliet AHM, Wood AC, Wooldridge K, Ketley JM, Henderson J. Genetic manipulation of enteric Campylobacter species. In: Peter Williams JK, George S, editors. Methods in microbiology. Cambridge: Academic Press; 1998. p. 407-19.

21. Skyberg J, Siek K, Doetkott C, Nolan L. Biofilm formation by avian Escherichia coli in relation to media, source and phylogeny. J Appl Microbiol. 2007; 102(2):548-54.

22. Reid AN, Pandey R, Palyada K, Whitworth L, Doukhanine E, Stintzi A. Identification of Campylobacter jejuni genes contributing to acid adaptation by transcriptional profiling and genome-wide mutagenesis. Appl Environ Microbiol. 2008;74(5):1598-612. doi:10.1128/aem.01508-07.

23. Ruiz C, Levy SB. Many chromosomal genes modulate MarA-mediated multidrug resistance in Escherichia coli. J Antimicrob Chemother. 2010:54(5):2125-34 doi:10.1128/aac.01420-09.

24. Langridge GC, Phan M-D, Turner DJ, Perkins TT, Parts L, Haase J, et al. Simultaneous assay of every Salmonella Typhi gene using one million transposon mutants. Genome Res. 2009;19(12):2308-16. doi:10.1101/ gr.097097.109.

25. Veeranagouda Y, Husain F, Wexler HM. Transposon mutagenesis of the anaerobic commensal, Bacteroides fragilis, using the EZ: TN5 transposome. FEMS Microbiol Lett. 2012;333(2):94-100.

26. Moran A, Upton ME. Effect of medium supplements, illumination and superoxide dismutase on the production of coccoid forms of Campylobacter jejuni ATCC 29428. J Appl Bacteriol. 1987;62(1):43-51.

27. Teh AHT, Lee SM, Dykes GA. Does Campylobacter jejuni form biofilms in food-related environments? Appl Environ Microbiol. 2014:80(17):5154-60

28. Parkhill J, Wren BW, Mungall K, Ketley JM, Churcher C, Basham D, et al. The genome sequence of the food-borne pathogen Campylobacter jejuni reveals hypervariable sequences. Nature. 2000; 403(6770): 665-668. http://www.nature.com/nature/journal/v403/n6770/ suppinfo/403665a0_S1.html.

29. Sun J, Deng Z, Yan A. Bacterial multidrug efflux pumps: mechanisms, physiology and pharmacological exploitations. Biochem Biophys Res Commun. 2014;453(2):254-67. doi:10.1016/j.bbrc.2014.05.090.

30. Kvist M, Hancock V, Klemm P. Inactivation of efflux pumps abolishes bacterial biofilm formation. Appl Environ Microbiol. 2008;74(23):7376-82. doi:10.1128/aem.01310-08.

31. Baugh S, Ekanayaka AS, Piddock LJV, Webber MA. Loss of or inhibition of all multidrug resistance efflux pumps of Salmonella enterica serovar Typhimurium results in impaired ability to form a biofilm. J Antimicrob Chemother. 2012:67(10):2409-17. doi:10.1093/jac/dks228.

32. Baugh S, Phillips CR, Ekanayaka AS, Piddock LJV, Webber MA. Inhibition of multidrug efflux as a strategy to prevent biofilm formation. J Antimicrob Chemother. 2014;69(3):673-81. doi:10.1093/jac/dkt420.

33. Donlan RM. Biofilms: microbial life on surfaces. Emerg Infect Dis. 2002:8(9):881-90.

34. Rosenberg M, Kjelleberg S. Hydrophobic interactions: role in bacterial adhesion. Advances in microbial ecology. Berlin: Springer; 1986. p. 353-93.

35. Bacon DJ, Szymanski CM, Burr DH, Silver RP, Alm RA, Guerry P. A phasevariable capsule is involved in virulence of Campylobacter jejuni 81-176. Mol Microbiol. 2001:40(3):769-77.

36. Jeon B, Muraoka W, Scupham A, Zhang Q. Roles of lipooligosaccharide and capsular polysaccharide in antimicrobial resistance and natural transformation of Campylobacter jejuni. J Antimicrob Chemother. 2009:63(3):462-8 
37. Nguyen VT, Barlow RS, Fegan N, Turner MS, Dykes GA. Role of capsular polysaccharides and lipooligosaccharides in Campylobacter surface properties, autoagglutination, and attachment to abiotic surfaces. Foodborne Pathog Dis. 2013;10(6):506-13.

38. Teh AHT, Lee SM, Dykes GA. The influence of prior modes of growth, temperature, medium and substrate surface on biofilm formation by antibiotic resistant Campylobacter jejuni. Curr Microbiol. 2016;73(6):859-66

39. Teh AHT, Lee SM, Dykes GA. The influence of dissolved oxygen level and medium on biofilm formation by Campylobacter jejuni. Food Microbiol. 2017;61(1):120-5

\section{Submit your next manuscript to BioMed Central and we will help you at every step:}

- We accept pre-submission inquiries

- Our selector tool helps you to find the most relevant journal

- We provide round the clock customer support

- Convenient online submission

- Thorough peer review

- Inclusion in PubMed and all major indexing services

- Maximum visibility for your research

Submit your manuscript at www.biomedcentral.com/submit
() Biomed Central 